\title{
Synthesis and Structure of a Single-Stranded Dihelicate of Copper (II) Involving Multiring Nitrogen-Heterocyclic Ligand
}

\author{
Nabanita Kundu*
}

Department of Chemistry, Lady Brabourne College, P-1/2, Suhrawardy Avenue, Kolkata 700017, India

*Corresponding author

A B S T R A C T

\begin{tabular}{|c|c|}
\hline Keywords & \\
\hline $\begin{array}{l}\text { Single stranded } \\
\text { dihelicate compound, } \\
\text { N- heterocyclic ligand, } \\
\text { X-ray diffraction } \\
\text { analysis, } \pi-\pi \\
\text { noncovalent } \\
\text { interactions, } \\
\text { Hydrogen bonding. }\end{array}$ & \multirow{3}{*}{$\begin{array}{l}\text { The single stranded-helicate Copper (II) complex }\left[\mathrm{Cu}_{2}(\mathrm{~L}) \mathrm{Cl}_{4}\right] \cdot \mathrm{H}_{2} \mathrm{O}(1) \\
\text { containing a new biologically relevant heterocyclic bis-bidentate ligand viz. } \\
3,3 \text {-dipyridine-2-yl-[1.1/]bi[imidazo }[1,5 \text {-a] pyridineyl] (L) has been } \\
\text { prepared and characterized by single-crystal X-ray diffraction analysis. The } \\
\text { molecule is centrosymmetric where coordination environments around } \mathrm{Cu} \\
\text { (II) are distorted tetrahedral }(\tau 4=0.36) \text {. The } \mathrm{Cu}(\mathrm{II})--\mathrm{Cu} \text { (II) separation is } \\
4.808 \AA \text {. Compound in its solid state structure shows } \pi-\pi \text { noncovalent } \\
\text { interactions as well as hydrogen bonding interactions that play dominant } \\
\text { roles in shaping the extended structure of the molecule. }\end{array}$} \\
\hline Article Info & \\
\hline $\begin{array}{l}\text { Accepted: } \\
\text { 04 July } 2017 \\
\text { Available Online: } \\
\text { 10 September } 2017\end{array}$ & \\
\hline
\end{tabular}

\section{Introduction}

The helical geometrical motif is found in natural as well as in artificial structures including spiral arm of galaxies, right and left handed quartz ${ }^{1}$, human art and architecture. In chemistry and biochemistry helicity is present in various systems ${ }^{2}$. The most important among these is deoxyribonucleic acid (DNA) which exists as a double helix in which the two strands are connected by hydrogen binding between complementary bases ${ }^{3}$. It stores and transmits our genetic make-up and therefore is essential for the sustenance of life.

Helicity can be introduced in artificial supramolecular architecture by introducing conformational restrictions in macromolecules, ${ }^{4}$ inter- or intramolecular hydrogen bonds, ${ }^{5}$ or coordination to metal ions. ${ }^{6}$

The term helicate was introduced by Lehn and coworkers in 1987 for metal complexes that contain one or more ligand strands and two or more metal centres. ${ }^{7}$ The number of coordinated ligand strands wraps about the metal centers in single, double and triple stranded helicates are one, two and three respectively. Identical coordinated strands lead to homostranded helicates while different ligand strands correspond to heterostranded helicates. Moreover coordinated ligand stands 
possessing similar binding units with similar intrinsic information lead to homotopic helicate whereas ligand strands possessing different binding units form heterotopic helicate.

The first metallohelicate analyzed by X-ray diffraction was described by Lehn et al., in 1987. It consists of two tris-(bipyridine) ligands and three $\mathrm{Cu}$ (I) ions. During the following decades, the helicate chemistry was dominated by ligands having bipyridine moieties $^{8-10}$ located at several strategic positions as such compounds find applications in many new research areas. ${ }^{11-22}$

Many transition metals with such ligands produce dihelicates. For dihelicates, double and triple stranded complexes of the types $\mathrm{M}_{2} \mathrm{~L}_{2}$ and $\mathrm{M}_{2} \mathrm{~L}_{3}$ where $\mathrm{L}$ is a bis-bidentate ligand, are particularly common. ${ }^{23-25}$ Much less common are single-stranded dihelicates where a single ligand coordinates to two nonbridged metal ions in a helical motif. ${ }^{26-28}$

Recently it has been observed that the weak or non-conventional hydrogen bonds like $\mathrm{C}$ H...O, O-H..., C-H... are crucial and play distinctive roles in structural chemistry and biology. ${ }^{29}$ The theoretical and experimental studies on such interactions may lead to the development of novel approaches for the design of effective systems capable of exhibiting noncovalent recognition properties at molecular level.

We have recently synthesized ${ }^{30,31}$ a $N$ heterocyclic compound, viz., 3,3'-dipyridin-2yl[1,1']bi[imidazo[1,5-a] pyridinyl] (L) containing a pair of biologically relevant ${ }^{32}$ imidazo[1,5-a]pyridine moieties. The ligand $\mathrm{L}$ is redox-active and capable of acting as a bisbidentate ligand, and its copper(II) compound offers a unique example of valence tautomerism in solution. ${ }^{31}$ Herein, we report the synthesis of a single stranded helicate
$\mathrm{Cu}$ (II) complex (1) of a nitrogen-rich heterocyclic ligand (L). The compound has been characterized by single-crystal X-ray diffraction analysis.

\section{Experimental}

Bis-bidentate type ligand $\mathrm{L}$ was prepared as described elsewhere. ${ }^{30,31}$ Copper chloride was purchased from Aldrich. All other reagents were commercially available and used as received. Solvents were reagent grade, dried by standard methods ${ }^{33}$ and distilled under nitrogen prior to their use. Elemental $(\mathrm{C}, \mathrm{H}$, $\mathrm{N}$, and $\mathrm{S}$ ) analyses were performed on a Perkin-Elmer model 2400 Series II CHNS Analyzer. The IR spectra were recorded on a Shimadzu model 8400S FT-IR spectrometer with samples prepared as $\mathrm{KBr}$ pellets.

\section{Synthesis and crystallization}

\section{$\left[\mathrm{Cu}_{2}(\mathrm{~L}) \mathrm{Cl}_{4}\right] \cdot \mathrm{H}_{2} \mathrm{O}(\mathbf{1})$}

A methanolic solution ( $5 \mathrm{~mL}$ ) of $\mathrm{CuCl}_{2} \cdot 2 \mathrm{H}_{2} \mathrm{O}$ (34 $\mathrm{mg}, 0.2 \mathrm{mmol}$ ) was carefully layered on to a solution of $\mathrm{L}(39 \mathrm{mg}, 0.1 \mathrm{mmol})$ in dichloromethane $(5 \mathrm{~mL})$. Diffusion between the two layers over a period of 10 days produced dark green crystals. Yield: $24 \%$. Anal. Calcd for $\mathrm{C}_{24} \mathrm{H}_{18} \mathrm{~N}_{6} \mathrm{Cu}_{2} \mathrm{OCl}_{4}$ : C, 42.67; H, 2.67; N, 12.45. Found: C, 42.85; H, 2.64; $\mathrm{N}, 12.18 \%$. FT-IR ( $\mathrm{KBr}$ pellet, $\left.\mathrm{cm}^{-1}\right): 3517$, $3454,1600,1502,1483,1461,1313,1245$, 781, 746, 696.

\section{Refinement}

Diffraction quality crystals of 1 (needle, dark green crystals, $0.13 \times 0.024 \times 0.016 \mathrm{~mm}^{3}$ obtained from $1: 1 \quad \mathrm{v} / \mathrm{v}$ dichloromethane/methanol) were grown by diffusion technique from the solvent combinations as noted. Crystal was mounted on glass fibers and aligned on a Bruker SMART APEX II CCD diffractometer. 
Intensity data for the compound was measured employing a monochromatized MoK $\alpha$ radiation $(\lambda=0.71073 \AA)$ source using phi and omega scan techniques at 296(2). In the case, absorption corrections based on multiscan using the SADABS software ${ }^{34}$ were applied. The structures were solved by direct methods $^{34}$ and least square refinement [anisotropic displacement parameters, hydrogen atoms in the riding model approximation and a weighing scheme of the form $w=1 /\left[\square^{2}\left(F_{0}{ }^{2}\right)+(a P)^{2}+b P\right]$ for $P=$ $\left.\left.\left(F_{0}{ }^{2}+2 F_{\mathrm{c}}{ }^{2}\right) / 3\right)\right]$ was on $F^{2} \cdot{ }^{34}$ Bruker SHELXTL $^{34}$ was used both for structure solutions and refinements.

Crystallographic parameters and the final residuals are given in table 1 . The positions of all non-hydrogen atoms were refined with anisotropic displacement factors. The water bound hydrogen atoms could neither be placed nor found and were therefore, omitted during the refinements.

\section{Result and Discussion}

\section{Synthesis}

Being partitioned into two bidentate binding domains, the ligand combines with $\mathrm{Cu}$ (II) metal salt in presence of inert counter anion chloride to form relatively rare $^{35}$ singlestranded dihelicate $\left[\mathrm{Cu}_{2}\left(3,3^{\prime}\right.\right.$-dipip $\left.) \mathrm{Cl}_{4}\right]$ (1) (Scheme 1). IR spectra of the complexes contain all the pertinent bands due to the coordinated bipyridine type ligands ${ }^{36}$ appearing at ca. 1600, 1485, 1461, 1313, $1247,770 \mathrm{~cm}^{-1}$ region as prominent features.

\section{Structure}

The molecular structure and the atom labeling scheme for 1 is shown in figure 1 and the relevant metrical parameters are compiled in table 2. The complex crystallizes in an orthorhombic space group $\mathrm{PbCn}$ with four molecular weight units per cell. The asymmetric unit comprises of one neutral binuclear species. The compound is centrosymmetric involving two $\mathrm{Cu}(\mathrm{II}) \mathrm{Cl}(1) \mathrm{Cl}(2)$ centers connected by one bridging bis-bidentate ligand $\mathrm{L}$ through $\mathrm{N}(1)$ and $\mathrm{N}(2)$ donors to form single stranded dihelicate. The $\mathrm{Cu}(\mathrm{II})-\mathrm{N} \quad(2.014(5)$ and 2.022(4) $\AA$ ) and $\mathrm{Cu}(\mathrm{II})-\mathrm{Cl}$ (2.242(15) and 2.248(17) $\AA$ ) bond lengths are consistent with the corresponding values found in analogues compounds. ${ }^{37}$ The $\mathrm{Cu}(\mathrm{II})---\mathrm{Cu}(\mathrm{II})$ separation is $4.808 \AA$.

The copper centers with +II oxidation states exist in highly twisted coordination environments. The sum of the bond angles of ca. $678^{\circ}$ at the copper centers are closer to the idealized value for a tetrahedral geometry (ca. $\left.657^{\circ}\right)$ rather than a square planer $\left(720^{\circ}\right)$ one. The $\mathrm{N}(1) \mathrm{Cu}(1) \mathrm{N}(2) / \mathrm{Cl}(1) \mathrm{Cu}(1) \mathrm{Cl}(2)$ dihedral angle is also significantly high $\left(36.19^{\circ}\right)$. Twisted environment around $\mathrm{Cu}$ (II) can also be explained by using the parameter $\tau_{4}$ developed by Houser et al., ${ }^{38}$ The expression for $\tau_{4}$ is shown by equation 1 .

Where $\alpha$ and $\beta$ are the largest angles in the four coordinate species. The calculated $\tau_{4}$ value (0.36) also suggests the environments around $\mathrm{Cu}$ (II) are distorted. Such a twisted four coordinated $\mathrm{Cu}$ (II) centers have significant relevance to enzyme active sites. ${ }^{39}$

There is a weak additional intermolecular interaction from $\mathrm{Cl}(1)$ to the copper center $\left(\mathrm{Cu}(1)^{\prime}-\mathrm{Cl}(1) \quad 2.744 \AA\right)$ of a adjoining molecule (Figure 2). In effect, to avoid steric repulsion, the strongly coordinated $\mathrm{Cl}$ atoms are drifted away from each other to generate compressed trans angles $[\mathrm{Cl}(2)-\mathrm{Cu}(1)-\mathrm{N}(2)$, $146.64^{\circ}$ and $\left.\mathrm{Cl}(1)-\mathrm{Cu}(1)-\mathrm{N}(1), 163.25^{\circ}\right]$. 
Table.1 Summary of X-ray crystallographic data for 1

\begin{tabular}{|l|l|}
\hline Parameter & $\mathbf{1}$ \\
\hline Composition & $\mathrm{C}_{24} \mathrm{H}_{16} \mathrm{Cl}_{4} \mathrm{Cu}_{2} \mathrm{~N}_{6} \mathrm{O}$ \\
\hline Formula wt. & 673.31 \\
\hline Crystal system & Orthorhombic \\
\hline Space group & $P b C n$ \\
\hline$a, \AA$ & $15.422(4)$ \\
\hline$b, \AA$ & $11.180(3)$ \\
\hline$c, \AA$ & $14.830(4)$ \\
\hline$\alpha$, deg & 90.00 \\
\hline$\beta$, deg & 90.00 \\
\hline$\gamma$, deg & 90.00 \\
\hline$V, \AA^{3}$ & $2557.0(11)$ \\
\hline$D_{\text {calc }}, \mathrm{Mgm}^{-3}$ & 1.75 \\
\hline Temp, K & $296(2)$ \\
\hline$\lambda, \AA$ & 0.71073 \\
\hline$Z$ & 4 \\
\hline$F(000) / \mu$ mm $^{-1}$ & $1344 / 2.113$ \\
\hline $\left.2 \theta_{\text {max }}{ }^{\circ}\right]$ & 41.76 \\
\hline Reflections Collected/Unique & $18179 / 1344$ \\
\hline$R_{\text {int }} / \mathrm{GOF}$ on $F^{2}$ & $0.0683 / 0.975$ \\
\hline No of parameters & 168 \\
\hline$R 1\left(F_{0}\right), w R 2\left(F_{0}\right)(I \geq 2 \sigma(I))$ & $0.0376,0.1110$ \\
\hline Largest diff. peak & 0.42 \\
\hline
\end{tabular}

Table.2 Selected bond distances $(\AA)$ and angles (deg) for 1

\begin{tabular}{|l|l|l|l|}
\hline \multicolumn{5}{|c|}{ Bond Distances $(\AA)$} \\
\hline $\mathrm{Cu}(1)-\mathrm{N}(1)$ & $2.014(5)$ & $\mathrm{Cu}(1)-\mathrm{Cl}(1)$ & $2.2422(15)$ \\
\hline $\mathrm{Cu}(1)-\mathrm{N}(2)$ & $2.022(4)$ & $\mathrm{Cu}(1)-\mathrm{Cl}(2)$ & $2.2487(17)$ \\
\hline \multicolumn{7}{|c|}{ Bond Angles $(\mathrm{deg})$} \\
\hline $\mathrm{N}(1)-\mathrm{Cu}(1)-\mathrm{N}(2)$ & $80.41(18)$ & $\mathrm{N}(1)-\mathrm{Cu}(1)-\mathrm{Cl}(2)$ & $94.62(14)$ \\
\hline $\mathrm{N}(1)-\mathrm{Cu}(1)-\mathrm{Cl}(1)$ & $163.25(13)$ & $\mathrm{N}(2)-\mathrm{Cu}(1)-\mathrm{Cl}(2)$ & $146.64(13)$ \\
\hline $\mathrm{N}(2)-\mathrm{Cu}(1)-\mathrm{Cl}(1)$ & $96.62(13)$ & $\mathrm{Cl}(1)-\mathrm{Cu}(1)-\mathrm{Cl}(2)$ & $96.66(6)$ \\
\hline
\end{tabular}

Scheme.1 Protocol followed for the synthesis of compound 1 
Fig.1 Molecular structure of 1 showing atomic numbering scheme.

Hydrogen atoms have been omitted for clarity

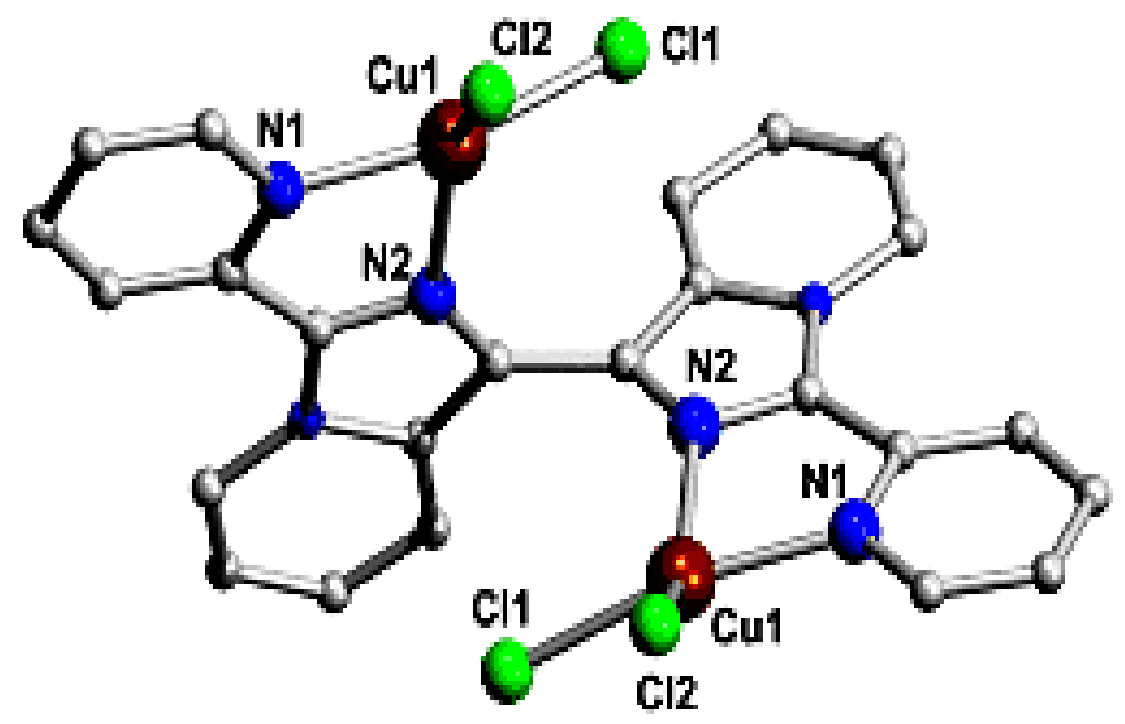

Fig.2 Partial view of the polymeric chain in 1

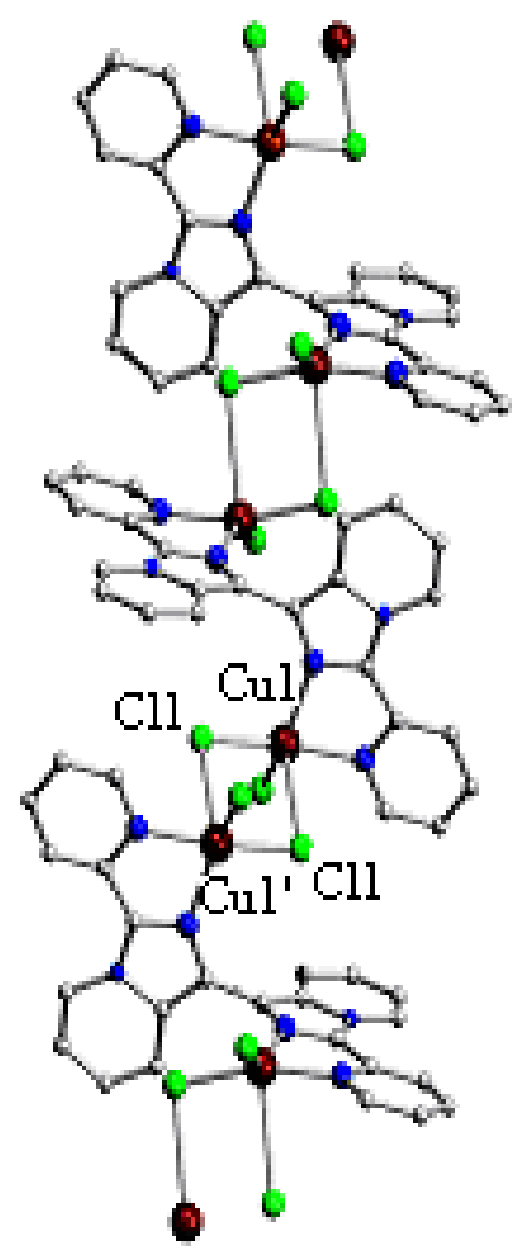


Fig.3 Representation of the F-type $\pi$ - stacking and hydrogen bonding interactions in 1 . Oxygen atoms of water molecules are represented in space-fill model

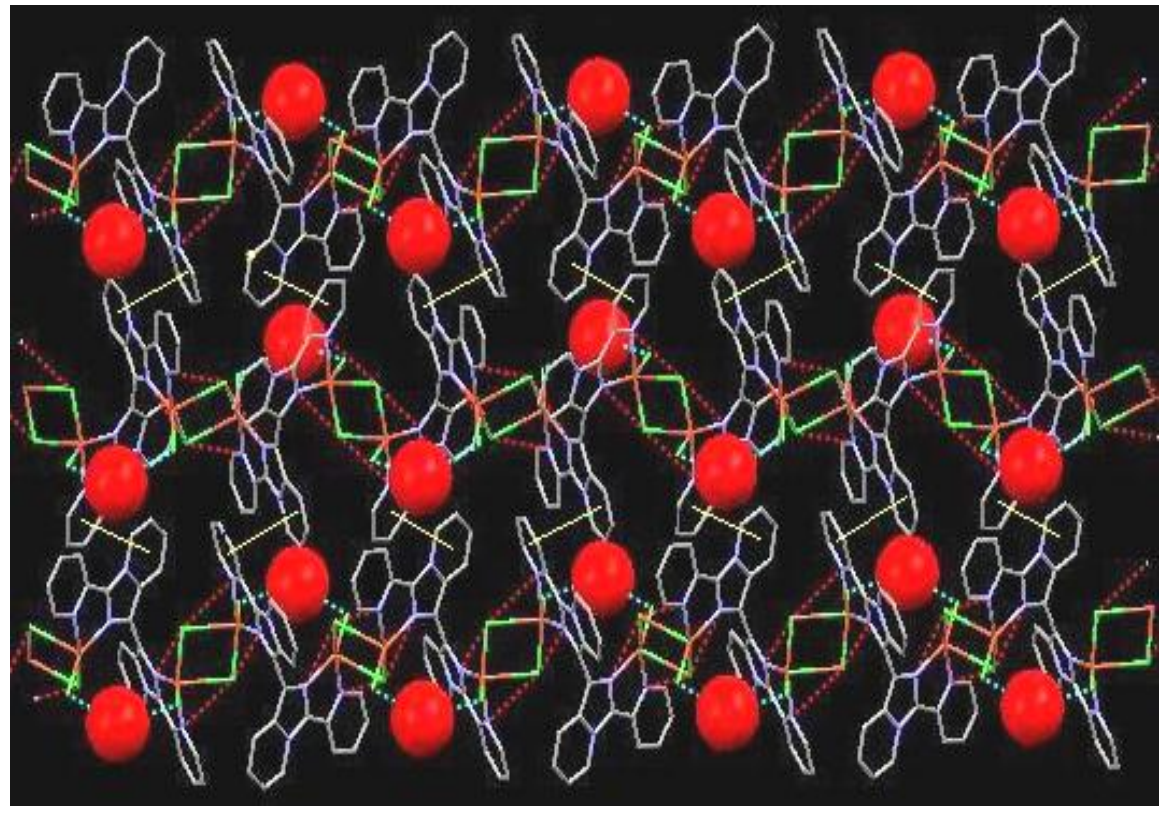

Finally, the dinuclear units are connected together intermolecularly by these weakly interacting $\mathrm{Cl}$ atoms which bind two adjacent $\mathrm{Cu}$ (II) centers of two dinuclear units ( $\mathrm{Cu}$ (II)$\mathrm{Cu}(\mathrm{II})^{\prime}$ separation $3.709 \AA \AA$ ), generating one dimensional oligomeric chain (Figure 2). Large im-im dihedral angle of $75^{\circ}$ in the bisbidentate ligand provides opportunities for the individual chains to stack via py-azopy overlapping creating aesthetically pleasing motif (Figure 3). These aromatic ring planes in the structure are separated by $3.579(4) \AA$ and dihedral angle between them is $10.95^{\circ}$, giving clear indication of slightly off target classical $\pi$ - $\pi$-stacking. The water molecules present in the compound participate in hydrogen bonding interactions with the coordinated $\mathrm{Cl}$ atoms (Figure 3).

Copper (II) complex (1) of the nitrogen-rich heterocyclic ligand (L) has been synthesized. The complex is dimeric with single-stranded helical topology. Finally, the dinuclear units are connected together intermolecularly by weakly interacting $\mathrm{Cl}$ atoms to generate one dimensional oligomeric chain The structure in the solid state involves multiple $\pi-\pi$ interactions. These noncovalent interactions play dominant role in shaping the extended structures of the compound in the solid state. Also compound establishes an array of hydrogen bonds that reinforce these noncovalent interactions in the molecule.

\section{References}

1. Jung, J. H.; Ono, Y.; Shinkai, S. Chem. Eur. J. 2000, 6, 4552.

2. Meyrer, K.P.; Vögtle, F. Top. Curr. Chem. 1985, 127, 1.

3. Watson, J. D.; Crick, F. C. H. Nature, 1953, 171, 737.

4. Berl, V.; Huc, I.; Khoury, R. G.; Krische, M. J.; Lehn, J.-M. Nature, 2000, 407, 420.

5. (a) Hanessian, S.; Simard, M.; Roelens, S. J. Am. Chem. Soc. 1995, 117, 7630. (b) Telfer, S. G.; Parker, N. D.; Kuroda, R.; Harada, T.; Lefebvre, J.; Leznoff, B. D. Inorg. Chem. 2008, 47, 209. (c) McMorren, D. A. Inorg. Chem. 2008, 47, 592. 
6. Feiters, M. C.; Nole, R. J. M. $A d v$. Supramol. Chem. 2000, 6, 41. (b) Lehn, J.-M. Chem. Eur. J. 2000, 6, 2097. (c) Han, L.; Valle, H.; Bu, X. Inorg. Chem. 2007, 46, 1511. (d) Gómez, L.; Company, A.; Fontrodona, X.; Ribas, X.; Costas, M. Chem. Commun. 2007, 4410.

7. Lehn, J.-M.; Rigault, A.; Siegel, J.; Harrowfield, J.; Chevrier, B.; Moras, D. Proc. Natl. Acad. Sci. U.S.A. 1987, 84, 2565.

8. Glasson, C. R. K.; Lindoy, L. F.; Meehan, G. V. Coord. Chem. Rev. 2008, 252, 940.

9. Kaes, C.; Katz, A.; Hosseini, M. W. Chem. Rev. 2000, 100, 3553.

10. (a) Piguet, C.; Bernardenelli, G.; Hopfgartner, G. Chem. Rev. 1997, 97, 2005. (b) Albrecht, M. Chem. Rev. 2001，101，3457. (c) Piguet, C.; Borcovec, M.; Hamacek, J.; Zeckert, K. Coord. Chem. Rev. 2005, 249, 705.

11. Oleksi, A.; Blanco, A. G.; Boer, R.; Uson, I.; Aymami, J.; Rodger, A.; Hannon M. J.; Coll, M. Angew. Chem. Int. Ed. 2006, 45, 1227.

12. Riss-Johannessen, T.; Harding, L. P.; Jeffery, J. C.; Moon, R.; Rice, C. R. Dalton Trans. 2007, 1577.

13. Jeffery, J. C.; Riss-Johannessen, T.; Anderson, J. C.; Adams, C. J.; Robinson, A.; Argent, S. P.; Ward, M. D.; Rice, C. R. Inorg. Chem. 2007, 46, 2417.

14. Cantuel, M.; Gumy, F.; Bünjli, J.-C. G.; Piguet, C. Dalton Trans. 2006, 2647.

15. Nitschke, J. R. Acc. Chem. Res. 2007, 40, 103.

16. (a) Harding, L. P.; Jeffery, J. C.; RissJohannessen, T.; Rice, C. R.; Jeng, Z. T. Chem. Commun. 2004, 654. (b) Hardling, L. P.; Jeffery, J. C.; RissJohannessen, T.; Rice, C. R.; Jeng, Z. T. Dalton Trans. 2004, 2396.
17. Telfer S. G.; Bocquet, B.; Williams, A. F. Inorg. Chem. 2001, 40, 4818.

18. Campos-Fernandez, C. S.; Schottel, B. L.; Chifotides, H. T.; Bera, J. K.; Baska, J.; Coomen, J. M.; Russel, D. H.; Dunbar, K. R. J. Am. Chem. Soc. 2005, 127, 12909.

19. Argent, S. P.; Adams, H.; RissJohannessen, T.; Jeffery, J. C.; Harding, L. P.; Mamula, O.; Ward, M. D. Inorg. Chem. 2006, 45, 3905.

20. Hasenknopf, B.; Lehn, J.-M.; Boumeidene, N.; Dupont-Gervais, A.; van Dorsselaer, A.; Kneisel, B.; Fenske, D. J. Am. Chem. Soc. 1997, 119, 10956.

21. (a) Dietrich-Buchecker, C. O.; Nierengerten, J.-F.; Sauvage, J.-P.; Armaroli, N.; Balzani. V.; De Cola, L. J. Am. Chem. Soc. 1993, 115, 11237. (b) Nierengerten, J.-F.; DietrichBuchecker, C. O.; Sauvage, J.-P. J. Am. Chem. Soc. 1994, 116, 375.

22. Uerpmann, C.; Malina, J.; Pascu, M.; Clarkson, G. J.; Moreo, V.; Rodger, A.; Grandas, A.; Hannon, M. J. Chem. Eur. J. 2005, 11, 1750.

23. Albrecht, M. Chem. Rev. 2001, 101, 3457.

24. Aspinall, H.C. Chem. Rev. 2002, 102, 1807.

25. Piguet, C., Bernardinelli, G., Hopfgartner, G. Chem. Rev. 1997, 97, 2005.

26. Morales, D., Perez, J., Riera, L., Riera V., Corzo-Suarez, R., GarciaGrandaand S., Miguel, D. Organometallics. 2002, 21, 1540.

27. Goodwin, H. A., Lions, F. J. Am. Chem. Soc. 1960, 82, 5013.

28. Barr, C. R., Jennings, M. C., Puddephatt, R. J., Muir, K. W. Organometallics. 1999, 18, 4373.

29. Desiraju, G. \& Steiner, T. The Hydrogen Bond; In Structural 
Chemistry and Biology, (2001). Oxford University Press.

30. Kundu, N., Abtab, S. M. T., Kundu, S., Endo, A., Teat, S. J., Chaudhury, M. Inorg. Chem. 2012, 51, 2652.

31. Kundu, N., Maity, M., Chatterjee, P. B., Teat, S. J., Endo, A., Chaudhury, M. J. Am. Chem. Soc. 2011, 133, 20104.

32. Knueppel, D., Martin, S. F. Angew. Chem., Int. Ed. 2009, 48, 2569.

33. Perrin, D. D.; Armarego, W. L. F.; Perrin, D. R. Purification of Laboratory Chemicals; $2^{\text {nd }} E d$. Pergamon: Oxford, England, 1980.

34. Sheldrick, G. M. Acta Cryst. 2015, C71, 3.

35. Prema, D.; Wiznycia, A. V.; Scott, B. M. T.; Hilborn, J.; Desper, J.; Levy, C. J. Dalton Trans. 2007, 4788 and the references cited therein.
36. (a) Sinha, S. P. Spectrochim. Acta. 1964, 20, 879. (b) Schilt, A. A.; Taylor, R. C. J. Inorg. Nucl. Chem, 1959, 9, 211.

37. Santillan, G. A.; Carrano, C. J. Inorg. Chem. 2007, 46, 1751.

38. Yang, L.; Powell, D. R.; Houser, R. P. Dalton Trans. 2007, 955.

39. (a) Wang, Y.; DuBois, J. L.; Hedman, B.; Hodgson, K. O.; Stack. T. D. P. Science 1998, 279, 537. (b) Kaim, W.; Rall, J. Angew. Chem. Int. Ed. Engl. 1996, 35, 43. (c) Masserschmidt, A. Struct. Bonding (Berlin), 1998, 90, 37. (d) Vila, A. J.; Fernandez, C. O. In Handbook on Metalloproteins, Bertini, A., Sigel, A., Sigel, H., Eds.; Marcel Dekker, New York, 2001, P183. (e) Harrison, M. D.; Dennison, C. ChemBioChem. 2004, 56, 1579.

\section{How to cite this article:}

Nabanita Kundu. 2017. Synthesis and Structure of a Single-Stranded Dihelicate of Copper (II) Involving Multiring Nitrogen-Heterocyclic Ligand. Int.J.Curr.Microbiol.App.Sci. 6(9): 247254. doi: https://doi.org/10.20546/ijcmas.2017.609.033 